University of Northern Colorado

Scholarship \& Creative Works @ Digital UNC

3-26-2020

\title{
Can Summer Philosophy Programs Help Close the Achievement Gap?
}

Bailie Peterson

University of Northern Colorado, bailie.peterson@unco.edu

Follow this and additional works at: https://digscholarship.unco.edu/philfacpub

Part of the Education Commons, and the Philosophy Commons

\section{Recommended Citation}

Peterson, Bailie, "Can Summer Philosophy Programs Help Close the Achievement Gap?" (2020).

Department of Philosophy Faculty Publications. 8.

https://digscholarship.unco.edu/philfacpub/8

This Article is brought to you for free and open access by the Department of Philosophy at Scholarship \& Creative Works @ Digital UNC. It has been accepted for inclusion in Department of Philosophy Faculty Publications by an authorized administrator of Scholarship \& Creative Works @ Digital UNC. For more information, please contact Jane.Monson@unco.edu. 


\title{
Can Summer Philosophy Programs Help Close the Achievement Gap?
}

\section{Bailie Peterson}

University of Northern Colorado

\begin{abstract}
While summer break presents educational and recreational opportunities for some students, students from depressed socioeconomic groups may face significant obstacles in the summer, including learning loss. In general, these students also lack access to a wide range of intrinsic and instrumental benefits attached to the study of philosophy. While there are currently existing philosophy programs, this contribution highlights the connections between summer experiences and the overall achievement gap, while identifying specific practices shown to yield successful summer programs. Philosophy provides an impressive set of benefits, including academic skills and opportunities for personal growth and development. Incorporating best practices while focusing on the methods and content of philosophy should, therefore, yield particularly rewarding programs. Due to these benefits, summer philosophy programs should be researched, developed, and expanded.
\end{abstract}

KEYWORDS: achievement gap, philosophy for children, summer enrichment, summer slide

\section{Introduction}

ALTHOUGH STUDENTS RARELY have the chance to study philosophy before college, there is considerable, demosnstrable value in teaching philosophy to elementary, middle, and high school students. In addition, the methods and content of philosophy courses could fill an unmet need for summer enrichment opportunities, which would be especially crucial for the most disadvantaged students. Although there are many methods to help these students, I will argue that summer philosophy programs offer a unique set of benefits, and therefore, should be developed, researched, and expanded. 
While there has been substantial work to argue for the benefits of philosophy, and, separately, to discuss methods to combat the gap in academic achievement that exists between students from different groups, my goal is to show that summer philosophy programs would not only aid in these efforts but could offer additional benefits.

I will begin by considering arguments that summer creates challenges that adversely affect the most disadvantaged students most. While there is some controversy about the relationship between summer and overall gaps in achievement among more and less advantaged students, I will include independent reasons to prioritize summer interventions. Next, I will provide reasons to support the growth of philosophy programs, in particular. I will end with reflections and suggestions for implementing summer philosophy programs, based on existing research and experiences working with $\mathrm{K}-12$ students.

Before going further, I'd like to address a concern that some readers may have. Given that philosophy is not included in standard pre-college curriculums, ${ }^{1}$ and, given the demands on teachers to ensure that students meet other learning outcomes during the school year, one might think that summer enrichment programs should be focused solely on improving core school-year skills. A related concern is that adding philosophy during the summer has no link to school year progress, and so, would not be able to affect the achievement gap.

In response, note that there are wide-reaching benefits to the study of philosophy, including the ability to improve the skill sets needed for success in the traditional classroom. If I am correct in my arguments below, summer philosophy programs could provide a novel means to serve students' needs both during the summer and when they return to the classroom. Setting further discussion aside, for now, I will first describe how differences in students' summer experiences can lead to challenges for economically disadvantaged students.

\section{The Impact of Socioeconomic Factors in and out of School}

Summer break varies widely for K-12 students, depending on factors like home life, access to enrichment, summer jobs, and family obligations. For many students, summer offers recreation, relaxation, and educational opportunities not always available during the school year. For others, however, summer not only lacks these benefits, but can be the source of setbacks in reading comprehension, math, personal development, and social skills (Alexander, Pitcock, and Boulay $2016,1)$. Primarily due to socioeconomic factors, these students are unable to access enrichment opportunities to allow for improvement, or even to maintain the academic progress they gained during the school year (ibid., 3; Alexander, Entwisle, and Olson 2007). Furthermore, summer break poses larger challenges, reflective of the overall network of issues referred to as the "achievement gap," or the gap in performance between students from different racial, ethnic, and socioeconomic groups on measures of academic progress. ${ }^{2}$ Although the effects 
of summer are just one part of a broad and complex set of social issues related to the achievement gap, my thesis specifically aims at improving student's summer experience as a means to affect a small part of a much larger issue.

\section{I.1. Student Summer Experiences}

While acknowledging factors that may impede the ability for all students to receive equal benefits during the school year (e.g., differences in teacher retention, class size, and school infrastructure), to a large extent, students receive the same educational content (Downey 2016, 13-14). In public K-12 schools, textbooks and supplies are low cost or provided, there are cost reductions or waivers for lunch, and school itself is free. Standards for teachers and grade-level curricula are set at the state or federal level, and lower performing schools may receive extra aid (Downey 2016, 14-15). In contrast, there is a significant disparity in what takes place outside of the school year.

This disparity can be made clear by considering reports from actual students. In June 2019, I taught a 2-week philosophy class for students in my local school district. ${ }^{3}$ The contrast between the experiences of two students in the class is illustrative of the role that socioeconomic factors play in students' summer experiences.

The first student lives in a rural community without reliable internet access or transportation. She is also responsible for childcare for her younger siblings while the adults are at work. Like many fourteen-year-olds, she was keen to establish her independence and enjoyed sharing her perspective in class. She found philosophical discussion particularly rewarding, as she was able to make supported arguments in favor of her views, rather than just sharing her opinions. This student expressed dismay as our session wrapped up, as the rest of her summer was anything but a vacation.

For another student, this class was merely one educational opportunity among many others. After sharing tales of international vacations and recreational activities, she let us know about the summer camp she would be attending the following month. I have the opportunity to teach philosophy there, as well, and am familiar with various aspects of the program, including the price tag-not exceptional for similar sleepover camps, but a clear obstacle for the rest of my June students. This camp was discussed frequently until another student expressed frustration and shared that she had attended the same camp on scholarship, in 5th grade, and had applied to return every year since. She wasn't selected, and the cost made it impossible for her to attend otherwise. A two-week intensive full-day camp, with a focus on academics and creativity, would boost learning progress far more than alternatives like sitting at home, watching TV, caring for siblings, working summer jobs (not all of which were enriching) or just killing time. The stark contrast between the students who could and could 
not participate highlights the need for free, subsidized, or affordable summer options.

\section{I.2. Statistics on Socioeconomic Factors}

Although these are individual anecdotes, these experiences reflect a general pattern found in the literature, based on factors directly related to socioeconomic status (SES). Consider the criteria the National Center for Education Statistics uses to compare homes in terms of socioeconomic status (NCES 2012). One assessment given to fifteen-year-olds, for example, is an index of home possessions. This includes a measure of the number of books in the home; wealth (as indicated by room of their own, internet link, dishwasher, DVD player); cultural possessions (like classic literature, art, and books of poetry); and home educational resources (like a desk and quiet place to study, a computer available for schoolwork, educational software, technical reference books, and a dictionary).

This study can help flesh out the contrast in home environments for students from different economic backgrounds. It is not difficult to see that homes with $0-10$ books will offer students exposure to a significantly smaller range of vocabulary, topics, authors, and viewpoints compared to homes with 500 or more books, the highest category in the NCES measure. Considering that these differences apply year-round, we can imagine that they have a strong impact in the summer when the primarily uniform school experience is removed and the time students inhabit drastically different worlds is increased.

The same report summarizes the findings of various researchers who argue in the same direction. For example, Spaeth's suggestion that "SES might indicate the complexity of a child's cognitive environment" and that some home environments better prepare students for school (1976, in NCES 2012, 13). Also, Levin and Belfield's claim that children from socioeconomically disadvantaged groups are less likely to have a "school-like" home environment or daily routine, and have weaker language interactions with parents (2002, in NCES 2012, 13). Additionally, the study highlights Walpole's observation "that low SES students also tend to have less access to cultural capital (specialized or insider knowledge not taught in schools) and social capital (contacts in networks that can lead to personal or professional gains; Coleman 1988) which have been argued to be key components of a students' educational success (2003, in NCES 2012, 13)."

These are all factors that take place outside of the classroom-at school, every student has access to a desk, basic supplies, and instruction. Efforts are made to reduce distractions, support different learning styles, and accommodate disabilities in the classroom. However, there are no independent standards to ensure that at home, students have desks and computers, a quiet study space, or access to books and positive, educationally enriching activities, which can cause them to fall behind academically. 


\section{I.3. Summer Learning Loss}

The fact that students fall behind during the summer has been noted since at least the turn of the last century (Pitcock 2018, 5), but came into critical discussion with the efforts of sociologist Barbara Heyns to explain what she observed in Atlanta, GA, in the 1970s. Heyns found that while black children and children from lower socioeconomic groups performed at the same rate during the school year, they fell behind during the summer months (Heyns 1978; 1987). Many contemporary scholars have arrived at similar results, arguing that students from socioeconomically disadvantaged families fall behind to a greater degree than their more advantaged peers.

In a collection exploring the impact of summer break on the achievement gap, Alexander, Pitcock, and Boulay argue that the gap stems primarily from what takes place at home, rather than in the classroom (2016). Various studies confirm these claims. For example, Atteberry and McEachin find evidence of summer learning loss through their analysis of the NEWA Measures of Academic Progress Assessment, a computer-adaptive test given in math, reading, science and social studies in districts across the nation $(2016,38)$. The authors included data from over 500,000 students in grades 2 through 9 and found that there was sufficient statistically significant data to support the claim that the achievement gap increases over the summer (ibid., 40). They argue that " $t]$ he results show how differences in summer experiences by themselves can lead to sizable achievement gaps over time. This illustrates that even in an ideal world where school inequities could be eliminated, achievement gaps would arise simply because of the summer break (ibid., 43-44)." ${ }^{\prime 5}$

Other researchers found similar results. For example, Entwisle, Alexander, and Olsen found that there was a reading comprehension gap between low and middle-income students, and that it that grew from half of a grade level in the fall of 1st grade to three grade levels by the spring of 5th grade, as a result of summer loss (1997). Further analyses suggest that these students were much more likely to drop out of high school, less likely to pursue a college preparatory track in high school, and unlikely to attend college (Alexander, Entwisle, and Olson 2007; 2014; Alexander and Condliffe 2016). Naturally, these differences in experience and achievement can lead to depressed economic prospects as adults, and further research highlights additional losses in overall learning, health and well-being, future career opportunity, and the support needed to break cycles of intergenerational poverty (Alexander, Pitcock, and Boulay 2016, 1).

There are clear reasons to consider the tremendous impact of the disparity between students' home lives outside of school, and especially over the summer break. It is possible to conclude that these at-home differences between high and low-income students are one of the root causes of the achievement gap.

It is important to note, however, that not all scholars agree with these results. For example, von Hippel and Hamrock (2019) contest previous studies, 
citing concerns related to data collection, and inconsistencies in reported results, leading them to question the extent to which score gaps increase in the summer $(2019,44) .{ }^{6}$ Nonetheless, they identify an achievement gap that is present previous to kindergarten $(2019,75)$. The authors further acknowledge that, even if the gap is in place before school begins, there are still worthwhile interventions, in elementary, middle, and high school (ibid.). ${ }^{7}$ Also, they provide independent reasons to promote summer learning programs, stating that " $\mathrm{t}]$ he potential of summer learning programs is clear from nearly every figure in this article. Although the figures do not consistently show that score gaps grow in summer, they do consistently show that summer learning is slow for nearly all children, including children from advantaged groups. [...] It is important to make the most of th[is] opportunity, through summer learning programs, through extended school years for disadvantaged children, or through policies that help poor parents and improve the home environments of disadvantaged children" (ibid., 76).

Therefore, even if summer loss plays less of a role in increasing, rather than maintaining, the achievement gap, summer programs nonetheless offer an excellent opportunity to provide disadvantaged youth with resources to help close the gap. My main argument, that summer philosophy programs should be expanded and could help reduce the gap, stands, even if the effects of summer learning loss are more nuanced than some scholars suggest. I will now provide support for the claim that summer programs are effective at increasing students' skills in areas like reading and math.

\section{Combatting the Summer Slide through Summer Enrichment}

\section{II.1.Summer Programs Can Help}

There is substantial evidence to show that summer learning programs can directly mitigate summer learning loss and improve students' knowledge base in areas including math and reading (Atteberry and McEachin 2016; Kim and Quinn 2013; McCombs et al. 2012; McCombs et al. 2015). The recent increase in programs and interventions to reduce summer loss further indicates significant support from both the federal and non-profit sectors, including the proclamation of a National Summer Learning Day, and grant opportunities directly for summer interventions. ${ }^{8}$

Reports from a variety of $\mathrm{K}-12$ summer programs lend further support, with evidence of significant gains for participants in programs in Boston, Baltimore, and Chicago, for example (Ackman, White, and Kim 2016; Roderick, Jacob, and Byrk 2004; Portz 2004). Federally funded programs like Upward Bound, which is shown to impact high school success and graduation rates in addition to increasing student learning, are further examples of successful summer interventions (Augustine et al. 2016). ${ }^{9}$ As long as the programs meet specific 
goals (as outlined in section IV, below), participants have been shown to improve their standardized test scores in the areas of most academic loss after completing summer programs (Augustine et al. 2016). Additional research highlights other benefits of summer programs, e.g., a positive impact on psychosocial well-being and self-esteem (Bohnert et al. 2016, 183-184).

It is also worth acknowledging that families affected by the achievement gap are likely to participate in these programs, as there are reports showing support and interest (Pitcock 2016; Deutsch 2017, v). 2014 surveys from the Afterschool Alliance, for example, show that 85 percent of families support funding for summer learning programs (Pitcock 2016, 72). Parents have significantly increased annual enrichment spending over the past forty years (Pitcock 2016, 71) and frequently list cost and proximity as the main reasons for selecting specific summer programs for their children (McLaughlin and Pitcock 2009, 2). If more low cost, local programs were introduced, families would be likely to take advantage of them (Pitcock 2018, 7). In addition to the demonstrable benefits, there appears to be significant interest, which provides strong reasons to develop summer programs.

\section{II.2. Other Summer Inequities}

Before moving on, it may be worthwhile to consider other differences in the distribution of summer obstacles and opportunities among students. This is, again, partially because the inequities between students are exacerbated when the mitigating effects of the more similar school year experience are removed.

On the health front, for example, consider that only 16 percent of students who qualify for free or reduced lunch access it in the summer months (Pitcock 2018, 6). This is due to many factors, including lack of availability, lack of awareness, and stigma about going to meal sites (ibid.). A related statistic is that summer weight gain for children increases in the summer months and affects economically disadvantaged students more than others (Bohnert, Zarrett, and Heard 2016, 162). This statistic is at odds with the idea of summer vacation as a time when students are outdoors and active-indeed, students who live in dangerous environments, or lack supervision, are often stuck indoors with little physical activity or outdoor entertainment (Pitcock 2018, 7). Because many children come from single-family homes, children are more often at home without supervision in the summer and are left to entertain themselves (Deutsch 2017, v).

There are also differences in access to health care, affordable housing, and safe neighborhoods. Exposure to crime increases for disadvantaged students when school is out, and a lack of access to community centers, including public parks and libraries, is a factor for some, including those from remote rural communities (Bohnert et al. 2016).

While these issues are not the specific focus of my paper, they too can be aided by summer enrichment programs. For example, if the community in 
which the intervention is to take place includes many food-insecure students, lunch can be included from the initial planning stages onward. Furthermore, the potential to focus on providing meals could be a way to secure funding. As Pitcock suggests, given that some federal programs provide grants for educational enrichment that include meals, including the National School Lunch Program Seamless Summer Option, and the Summer Food Service Program, including this in program design could serve multiple purposes (Pitcock 2016, 74). In general, prior awareness of the challenges students face in the summer makes it possible to build programs specifically designed to counter them.

I will now highlight additional factors that make summer philosophy programs particularly beneficial.

\section{The Benefits of K-12 Philosophy}

\section{III.1. General Benefits}

At this point, it should be clear that summer inequities, including learning loss, are significant issues, and that a variety of summer programs could help, especially for the most disadvantaged students. One might wonder what is special about philosophy programs, as opposed to other options. While I believe that there are strong reasons to develop summer interventions overall, and, in particular, programs that attempt to aid the least advantaged children, philosophy is an effective, independently valuable, and important subject to include.

I want to advance the thesis that summer philosophy programs will not only help with summer learning issues but will simultaneously encourage individual benefits, including socio-emotional growth and personal satisfaction. Also, programs that are designed based on the goals I set out below would help combat other aspects of the achievement gap; e.g., potentially increasing college enrollment and completion for underrepresented students. Further benefits to the field of philosophy are also possible, as discussed below.

In the United States, the efforts of philosophers beginning around the 1970s, especially Matthew Lipman, Ann Margaret Sharp, and Gareth Matthews, helped form the foundation of sustained efforts to bring philosophy into the pre-college classroom..$^{10}$ These efforts have helped spearhead national and international support and have led to significant research favoring pre-college philosophy. For example, there is strong empirical evidence that studying philosophy before college develops and sharpens skills related to reading comprehension, analytic reasoning, and logic (Trickey and Topping 2004; 2007), as well as improvement on those portions of standardized tests evaluating problem-solving skills (Frederick 2005). In addition to these types of skills, studies link philosophy programs in $\mathrm{K}-12$ schools to an increase in socio-emotional growth, independent thinking, and positive self-esteem (Millet and Tapper 2012; Mohr Lone and Burroughs 2016). Finally, further research supports the ways that students can improve 
performance when they take a personal interest in their learning (Fredricks, Blumenfeld, and Paris 2004; Martin 2001; Kizel 2016). Philosophical education provides an impressive range of both intrinsic and extrinsic goods.

These rewards may be reflected at the university level as well, where philosophy majors are known to outperform all other majors on the Law School Admission Test and the verbal and analytic reasoning segments of the Graduate Record Examination. ${ }^{11}$ Philosophy majors perform well above average on the Graduate Management Admission Test and have higher mid-career salaries than students with 4-year degrees in most other humanities and social science majors. ${ }^{12}$ If these results can be shown to stem from the study of philosophy, rather than demonstrating that students likely to do well on these tests tend to study philosophy, it strengthens the case for increasing the reach of the field. ${ }^{13}$ Encouraging an interest in philosophy benefits $\mathrm{K}-12$ students immediately, and if their interest leads them to pursue university study or take further philosophy courses, these benefits may compound.

\section{III.2. The Community of Inquiry and Philosophy for Children}

Because philosophy relies on various methods and covers an impressive breadth of topics, it is useful to focus on some of the specific goals within the practice of philosophy for children, when identifying benefits. Rather than viewing the field as a particular body of knowledge, we can understand philosophy for children as an approach to a wide range of questions, capable of being tailored to individual interest, and dedicated to encouraging "philosophical sensitivity" (Mohr Lone 2012; 2013, Mohr Lone and Burroughs 2016). Although there are differences in approach, there are common goals and methods within the practice of philosophy for children. For example, the method of Community of Inquiry is an approach used by many who work in philosophy for children and can be defined as "a group of individuals who collaboratively engage in purposeful critical discourse and reflection to construct personal meaning and confirm mutual understanding (Garrison 2011, 15, quoted in Mohr Lone and Burroughs 2016, 53)." This is a Learner-Centered model that involves a focus on student's development, articulation, and support of their views rather than, e.g., an ability to recite specific facts (Wartenberg 2009, 18). With this method, students direct the course of the investigation, and that dialogue itself can provide evidence of the success of the lesson (ibid.). ${ }^{14}$

Asking students to reflect on questions that mean the most to them, and allowing them to present, critique, re-work and re-evaluate the views of others as well as their own, can be a source of personal pride and satisfaction as well as a way to build knowledge and relevant skills. This approach hones students' abilities to consider and respond to diverse points of view while enabling selfreflection and increasing engagement. 
Although philosophy is not currently a part of the required K-12 curriculum for most US schools, the rewards of studying philosophy can have a direct impact on the foundational skills needed for success during the school year.

\section{III.3. Reading Comprehension and Math Skills}

In particular, recent UK studies of over 3,000 elementary school students have shown positive gains in both math and reading through the study of philosophy. These studies also suggest that students who are most disadvantaged gain more in these areas as compared to their peers. ${ }^{15}$ Because philosophy instruction can lead to several months' progress in the two areas of most substantial summer learning loss, completing philosophical education over the summer could perhaps do the most to help these students. ${ }^{16}$

Reading comprehension, one of the most significant areas of loss over the summer, is vital to the practice of philosophy. Exercises in philosophy often involve carefully reading and discussing a piece of writing, getting clear on what takes place, and directly identifying the parts of the text that indicate arguments, conclusions, and support. Even with very young children, the practice of philosophical discussion emphasizes these skills. For example, Thomas Wartenberg's approach focuses on reading age-appropriate picture books as part of a community of philosophical inquiry with children (Wartenberg, e.g., 2009; 2019). ${ }^{17}$

Research on the effects of summer reading programs on the socioeconomic achievement gap is promising, as discussed above (Allington and McGill-Franzen 2018). Therefore, maintaining a focus on reading while introducing philosophical content and methodology into a summer program would bring about the benefits of philosophy while simultaneously improving reading skills.

The link to mathematics, (another main area of summer loss), is also worth further exploration. In addition to the long history of collaboration and crosspollination between these fields, (e.g., the work of philosophers like Descartes, Leibniz, and Russell), contemporary philosophers, like Paul Benacerraf and Penelope Maddy, have continued the conversation within the field today (Gold and Simons 2008). The skills honed in philosophy have deep ties to the study of math, and both subjects share a reliance on abstract thinking, methods of proof, thought experiment, and conditional analysis. Practicing these skills in many settings can provide the scaffolding needed to improve in both subjects.

Approaching a problem or topic from multiple perspectives is known to improve student learning outcomes, as well. For example, these ideas are reflected in the methods of "depth and complexity" in gifted education (Kaplan 1994), ${ }^{18}$ and the general approach of interdisciplinary or cross-curricular teaching, which helps students think critically, and retain what they are learning (Repko 2009; Repko, Newell, and Szostak 2011). Asking questions in the philosophy classroom, (e.g., "Are numbers real?", "Did we discover, or invent, math?") can ignite an interest that continues when students return to math class. While there is 
room for further study to see the direct impact of various philosophical techniques on mathematical skills, there are reasons to believe that they could be mutually supportive.

Returning to the concern noted in the introduction, the links between developing philosophical skills and improving in required core areas like reading comprehension and mathematics should be clear, and helps bolster the case for summer philosophy as a response to learning loss. I want to argue further that these programs can do even more to help mitigate the effects of the summer obstacles faced by young people from disadvantaged backgrounds while providing additional benefits.

\section{III.4. Stages of Development}

A unique benefit, especially for students in 5 th through 12 th grade, is that philosophy can provide a novel approach to questions that are of immense interest and importance to young people, which are often otherwise left unaddressed. Lateelementary, middle, and high school students fall into what many psychologists recognize as an essential stage of both cognitive change (Arain et al. 2013) and social-emotional development, including attempts to establish independence and determine their identity (Erikson 1963; 1968; Marcia 1980). Philosophical exploration of the big questions of the human condition can provide a guided, critical examination of these issues. For example, philosophical methods can provide resources for students to fruitfully discuss and find comfort in responding to questions about death, God, meaning, and identity at the forefront of their minds, which may otherwise be a source of frustration or confusion. Experience working with middle and high school students supports these claims. ${ }^{19}$

\section{III.5. Adding Voices to the Field}

The fact that philosophy classes typically exist in universities has meant that students who do not attend college have not had access. While the demographics of college students are changing, restricting philosophy primarily to higher education means that many underrepresented students will not have the opportunity to experience the personal and academic benefits of the subject. This is a mistake, as the ability for philosophy to open minds and increase wonder should not be determined by upbringing or class.

At the same time, philosophy itself would benefit from including a wider range of voices, at all levels. The field is plagued by a lack of diversity. ${ }^{20}$ Increasing pre-college exposure could help more students discover their interests, which could help bring a broader audience to the field.

\section{III.6. Benefits of University-based Philosophy Programs}

The fact that philosophy programs exist primarily within colleges and universities can lead to important opportunities for K-12 students, as well. If programs 
are housed within, or otherwise attached to a university or college, this can increase their benefits, especially for future first-generation students, and others underrepresented in higher education. This hypothesis can be supported by considering elements of my own teaching experience, as well as recent literature on issues faced by underrepresented college students.

This summer, I taught three philosophy classes in two settings, both of which took place on campus at a public university. One class was offered free of cost for 9th and 10th graders in my school district. In this particular class, all but one student was first-generation, and most came from financially disadvantaged backgrounds and underrepresented racial and ethnic groups. Considering that studies connect college campus visits with the likelihood to attend for first-generation students, this could help to counteract other elements of the achievement gap (Swanson et al. 2019, 2, 19-25). In particular, first-generation students may find the college environment to be very psychologically intimidating, and so offering low-stress, high reward interactions could go far to bring these students back to campus to pursue degrees (ibid., 2). Other studies highlight the immense importance of positive interactions between professors and first-generation students. For example, Hutchison argues that first-generation students have very different perceptions of faculty, which may impede their ability to succeed $(2017,2)$. Given that these students are unlikely to interact with professors before entering college, it is important to avoid initial negative interactions and provide opportunities to connect. Counteracting negative perceptions ahead of time could help students feel comfortable enough to seek assistance as needed after they arrive on campus. ${ }^{21}$ Connections with faculty could help fight the lower enrollment, retention, and graduation rates faced by underrepresented students, and could make their college experience more enjoyable while increasing success. ${ }^{22}$

As mentioned above, this short-term in-district philosophy course was designed to include on-campus lunch for participants. Eating in the dining commons allowed a more in-depth experience of campus life, and also helped circumvent issues related to summer food scarcity. This lunch period also offered opportunities to deepen connections with college students and faculty. For example, because class participants sat with college students at lunch, they were able to talk informally. I observed changes in the topics and depth of discussion over time. Participants asked broad and abstract questions at the start; e.g., whether their student mentors liked college, and where they grew up. Over time, questions became specific enough to lead me to believe that participants were able to picture themselves more readily as potential college students. By the end, the participants' questions moved to specific majors offered, financial aid, student groups, scholarships, and the challenges and benefits of living with roommates 
Another strength of university-based programs is the strong potential to increase community engagement and teaching opportunities for undergraduates. Because the Community of Inquiry method is demonstrable, students (especially those who have taken multiple philosophy courses), can soon facilitate lessons and lead discussions. This practice not only allowed the middle and high school students to interact with their near peers, but it also provided further examples of the variety of people who can be university students as well as shattering stereotypes about who can be a philosopher. ${ }^{23}$ University students gained a lot from this experience as well, and several participants are seeking further teaching opportunities as a result. Hosting summer programs at a university or college can yield many rewards and, therefore, should be a part of program design, when possible.

\section{III.7. Existing Summer Philosophy Programs}

A look at existing summer philosophy programs provides further support for their increase. A strong example is Columbia University's Center for American Studies' Freedom \& Citizenship program, an intensive summer seminar with a focus on philosophy, and connections to civics. Students read classics in philosophy alongside contemporary articles and produce original work in response. The program boasts incredibly encouraging outcome statistics, with $99 \%$ of their graduates enrolling in college within six months, $83 \%$ of their students earning a bachelor's degree in four years, and $99 \%$ within six years. ${ }^{24}$ They also report a substantial increase in community engagement in college and after. Because the program targets underserved youth, its impact is even more significant, and the results especially noteworthy.

Other summer philosophy programs can provide further models and goals for successful outcomes. Philosopher Clair Katz, for example, has designed and led a successful summer program at Texas A \& M University since 2016 and has outlined and shared her model. ${ }^{25}$ Further examples include California Lutheran University's Summer Philosophy Academy, ${ }^{26}$ Ohio State University's PACT Philosophy and Critical Thinking Summer Camp ${ }^{27}$ Prindle Institute for Ethics Express CAMP, ${ }^{28}$ Iowa Lyceum for high school students, ${ }^{29}$ Utah Lyceum summer program, ${ }^{30}$ and the Kenan Institute for Ethics at Duke University's Arete High School Summer Seminar in Ethics, Philosophy and Religion. ${ }^{31}$

There is a precedent for summer philosophy programs, and the benefits of various programs show their strengths. My main goals are to encourage further opportunities, and, importantly, to ask for an increase in data collection, to be used to bolster new efforts. I will now discuss evidence-based reasons for specific program design elements, all of which are compatible with summer philosophy programs. 


\section{Best Practices for Summer Programs Applied to Philosophy}

Summer programs do not always have the goal of collecting data (Pitcock 2018, 8; Borman, Schmidt, and Hosp 2016). Furthermore, as Phillps argues, there are challenges in determining what to test and how (2018: 44). These issues can make it difficult to evaluate best practices, and, therefore, to find reasons to support the development of new programs. Fortunately, recent efforts have been made to identify the most effective summer program practices and policies. For example, Borman, Schmidt, and Hosp studied summer programs in 16 states and highlighted several essential practices (2016). They found that selecting and adopting a specific, evidence-based intervention was the most important criterion.

This goal can easily be included in a summer philosophy program, especially if directors rely on the methods used in established programs. As discussed above, there is a well-supported body of literature on the method of the Community of Inquiry and its results, which makes this approach an important option. This method can be tied to the literature on Learner-Centered Teaching, as well, which has been shown to increase a variety of necessary and essential skills, especially for students who are affected by the achievement gap (Friedlaender et al. 2014). Furthermore, curricula can be fine-tuned to align with the program goals of school districts or other organizations to develop and produce the most appropriate program.

Further examples of best practices include appropriate duration; small class sizes and a focus on smaller group discussions; methods of tracking and encouraging attendance; and, a focus on evaluating student learning outcomes. These criteria are similar to the findings of a meta-analysis conducted by McEachin, Augustine, and McCombs, who also found that small class size, high-quality instruction, and policies to increase attendance and participation were essential to a successful summer program $(2016,204)$. All of these goals are compatible with a philosophy-focused summer learning program, and the Community of Inquiry approach is especially well-suited to the discussion related goals.

The authors further suggest that aligning the course content to reflect particular student interests (e.g., letting students choose which books to read) was extremely beneficial, as well as having a site culture that encourages learning and involvement (McEachin, Augustine, and McCombs 2016, 204). Other goals include encouraging parental involvement and helping to meet the needs of parents by providing meals and transportation for students (Borman, Schmidt, and Hosp 2016, 95).

Again, philosophy is a broad field with much flexibility, and so, specific programs could rely on proved methods of philosophy for children while narrowing their focus to impact particular gaps and interests. All of the above practices are compatible with the methods of philosophy.

There are many ways to enact summer philosophy programs, and a range of programs are likely to produce measurable, positive outcomes. While there is 
a need for more data to identify, e.g., a specific threshold for the number of hours or amount of content, one goal of writing this is to support the need for more research. Creating more programs and carefully tracking data will help identify further goals. Those interested in development can look to the best practices, as well as considering the strengths of existing programs. There are many online resources available, as well. ${ }^{32}$

In addition, there are many opportunities to collaborate with other organizations in addition to creating new stand-alone programs. Options to consider include federally supported programs dedicated to increasing success in higher education (like Upward Bound), working with public libraries, school districts community organizations, university-sponsored summer camps, or non-profit organizations.

Given that summer enrichment programs are currently receiving attention and support, it is a good time to unite these efforts with the goals and benefits of philosophy for children. Bringing philosophy for children into summer education programs will make them attractive to a wider audience, and would meet many goals simultaneously.

\section{Maintaining the Special Benefits of Philosophy}

In closing, I would like to acknowledge and respond to one further concern. This essay is, overall, an attempt to argue that since studying philosophy provides us with significant instrumental benefits, we must increase summer programs and bring the field to a wider range of students. Kristopher Phillips has argued that, if one makes these goals the specific focus of philosophy programs, we risk losing the intrinsic rewards that make philosophy special (e.g., cultivation of the philosophical self; improving a specific form of rationality referred to as 'reasonableness', and developing a sense of wonder) $(2018,45)$. The concern is that if programs do not aim to get students to do philosophy, rather than learn about philosophy, the students will miss out on valuable, non-instrumental benefits.

I believe that we can heed these concerns while still pushing for further data collection and development of the sorts of programs I advocate above. Although one can imagine a philosophy class in which students merely memorize facts about what various key figures did or thought, the philosophy programs I envision do not follow this model. Indeed, it is not clear that such content would yield instrumental rewards, and the results discussed in section III depend on using a method that emphasizes goals like collaborative discourse. In the UK studies cited above, for example, teachers completed training centered around a method similar to the community of inquiry approach. ${ }^{33}$ When proposing new programs, advocates can claim to expect similar positive results only if they rely upon similar models and methods. Therefore, intrinsic engagement with philosophy may be necessary for instrumental gains. 
Phillips's argument can help to highlight benefits that may be overlooked by those less familiar with philosophy, but which are no less important than the pragmatic goals. I agree that we ought to share these benefits with as many students as possible. Furthermore, I believe that we can meet the goal of encouraging and increasing access to the special benefits of philosophy while seeking support from policy-makers, funding agencies, and school districts, which may be concerned primarily with the more concrete benefits.

\section{Conclusion}

I have attempted to demonstrate the need for summer philosophy programs by presenting a wide array of benefits, including potential improvement in the most needed skills for classroom success, opportunities for growth and personal development, the possibility to increase access to higher education and add voices to the field, and the means to overcome other summer-specific concerns-especially a lack of enrichment options-that could exacerbate the achievement gap. I hope that the arguments above can create space for additional opportunities to bring the intrinsic rewards of philosophy to more students, while simultaneously promoting practical benefits that could help the least advantaged students most.

\section{Notes}

1. Note that there is growing support, both nationally and internationally, for pre-college philosophy. For example, see The International Council of Philosophical Inquiry with Children, an organization dedicated to supporting the increase of philosophical inquiry with children, around the world. ICPIC lists sixty countries practicing philosophy for/with children, in six continents. Many countries in Europe, Latin America, and other parts of the worlds also offer or include philosophy as part of standard curriculum before college. See http://my.icpic.org.

2. For example, white-non-Hispanic students, and students from higher socioeconomic groups, outperform their peers from other groups. See, for example, National Education Association "Students Affected by Achievement Gaps" http://www.nea. org/home/20380.htm. This page contains links to various NEA and Educational Testing Service studies highlighting the gaps in test scores based on differences in race, ethnicity, sex, and socioeconomic status. See, also, reports on the issue from the National Center for Education Statistics: https://nces.ed.gov/nationsreportcard/ studies/gaps/, as well as discussion in Berliner 2009.

3. This took place within my school district, which is among the lowest in terms of per-pupil funding in the state, thus providing the opportunity to work with disadvantaged and under-represented students. Many students and their families struggle, financially, and therefore, this course did not include fees. This was made 
possible due to support from Weld County District 6 (who provided funds for student lunches), the American Philosophical Organization (who provided funding for University student lunches and classroom supplies), and time and effort of students, administrative assistants, and professors. In addition to the APA and District 6, I would like to acknowledge Dr. Deborah Romero, Dr. Jeff Brown, Renee Dent, Nate Evans, and Arianna Borroto for their assistance.

4. The authors reference further studies, including national reports from Downey, von Hippel, and Broh 2004, Lee and Burkham 2002, and literature reviews, including Cooper et al. 1996.

5. See also Deutsch 2017, Hall et al. 2017, Terzian, Anderson Moore, and Hamilton 2009, and Miller 2007.

6. See, also, Koury et al. 2019.

7. For example, they highlight successful programs, discussed in Tuttle et al. (2013), and Dobbie and Fryer (2011).

8. Proclamation No. 8395, 74 Fed. Reg. 33135 (Jul. 9, 2009).

Regarding funding opportunities, Pitcock $(2016,72)$ suggests linking to summer nutrition programs like TANF, and the Summer Food Service Program, which has a dedicated budget for summer enrichment programs. There are also summer-specific funding opportunities through the department of education, including those for programs to help schools with a high percentage of low-income students. For example, consider 21st Century Community Learning Centers Grants, and Title I, Education for the Disadvantaged Programs. See http://www2.ed.gov/programs/21stcclc/index. html and https://www2.ed.gov/programs/titleiparta/index.html.

9. For further information, see https://www2.ed.gov/programs/trioupbound/ grantee-level.html.

10. See, for example, Lipman 1988; Lipman and Sharp 1979 and 1988; Matthews 1980 and 1984; and Sharp 1987.

11. Educational Testing Services Report; ets.org.

12. See, e.g., the recent Wall Street Journal analysis at http://online.wsj.com/public/ resources/documents/info-Degrees_that_Pay_you_Back-sort.html.

13. While noting the correlation between majoring in philosophy and graduate test scores, it is important to acknowledge the possibility that these results reflect the fact that those who major in philosophy tend to come from more privileged backgrounds, and, therefore, may be better prepared for college and more likely to do well on these tests. Although the positive impact on critical thinking and problem-solving skills at the pre-college level has been established, further research is needed to determine the effects of the study of philosophy in college on these graduate test scores.

14. See also, Mohr Lone and Burroughs 2016.

15. See https://educationendowmentfoundation.org.uk/projects-and-evaluation/projects /philosophy-for-children/ and https://educationendowmentfoundation.org.uk/ 
projects-and-evaluation/projects/sapere-philosophy-for-children-effectivenesstrial. Note that results from the second, larger study, will be published by the Spring of 2021.

16. The studies referenced including short weekly philosophy lessons over the course of a school year. More research is needed to identify the amount of instruction time that yields these positive results, but it is reasonable to assume that longer lessons, taught more frequently over a shorter time period, could provide similar gains. Analogously, summer reading programs (like those mentioned in section II) have improved skills significantly in a short period of time.

17. See also Kenyon, Terorde-Doyle, and Carnahan 2019.

18. Dr. Kaplan provides links to Open Educational Resources on Depth and Complexity on her website as well. See http://www-bcf.usc.edu/ skaplan/

19. For example, 9th and 10th grade students were asked to select examples of beautiful songs, based on Terrance McKittrick's lesson plan (in Mohr Lone and Burroughs $2016,152)$. Unexpectedly, this yielded many songs with a focus on suicide and death. We were able to pause and have a focused discussion on value and meaning before returning to the question of beauty. Not only does this highlight the sorts of questions students in this age-range may bring to the table, it also demonstrates the flexibility of the methods supported in Community of Inquiry. Instead of setting the topic aside, we discussed various approaches to the questions raised by the class.

20. The American Philosophical Association estimates that, e.g, 17\% of those who earn bachelor's degrees in philosophy are from racial and ethnic minority groups, and $30 \%$ of those who earn philosophy degrees at all levels are women. https://www. apaonline.org/resource/resmgr/data_on_profession/minorities_in_philosophy.pdf and https://www.apaonline.org/resource/resmgr/Data_on_Profession/Women_in_ Philosophy.pdf. See also https://www.apaonline.org/page/diversity_resources. This page contains many resources and suggestion to increase diversity in philosophy, including efforts to increase philosophy classes offered at every level. Our ability to understand the connection between philosophy and high graduate test scores would also be aided by increased diversity in the field, as it would enable us to confirm or rule out the potential selection bias.

21. Underrepresented students may also suffer from "Imposter Syndrome," which describes feelings of "Intellectual phoniness" first discussed by Clance and Imes (1978), in response to studies on high-achieving women. These negative feelings can impede student progress, and can cause, e.g., mental distress as well (see Cokley et al. 2017). Increasing feelings of belonging is, therefore, an important goal.

22. For example, there is a 19 percentage-point gap between first-generation students and continuing generation students when it comes to college enrollment (Cataldi et al. 2018).

23. Students in the district class were exposed to a variety of representations of experts in philosophy, including first-generation students, people of color, women, 
people with disabilities. This is reflected by course evaluations, which included comments like "anyone can be a philosopher." Changing the views of upcoming generations regarding what philosophy is, and who can take part, could have long-term benefits for the professions and the potential to increase diversity.

24. See https://freedomandcitizenship.columbia.edu/.

25. See http://p4ctexas.sites.tamu.edu/. For an interview discussing the details of the Camp, see also https://www.plato-philosophy.org/pre-college-philosophy-summercamp-texas/.

26. https://www.callutheran.edu/special-events/philosophy-academy/.

27. https://philosophy.osu.edu/pact.

28. https://www.prindleinstitute.org/community-engagement/express-camp/.

29. https://clas.uiowa.edu/philosophy/outreach-engagement/iowa-lyceum.

30. http://suu.edu/utahlyceum.

31. https://kenan.ethics.duke.edu/arete-high-school-summer-seminar-in-ethicsphilosophy-and-religion-2019/.

32. A good starting place is the guides available through the Philosophy Learning and Teaching Organization (PLATO), e.g., the PLATO Development Handout, and guide to pre-college philosophy. See https://www.plato-philosophy.org/ wp-content/uploads/2017/04/PLATO-Development-handout.pdf and https://www. plato-philosophy.org/pre-college-philosophy. PLATO is an organization dedicated to "enriching children's educational experience by introducing them to the benefits and rigors of philosophy before they graduate from high school." See https://www.platophilosophy.org/why-plato.

33. The training for these classes was conducted by SAPERE, the Society for the Advancement of Philosophical Enquiry and Reflection in Education, a national charitable organization supporting philosophy for children in the UK. The methods supported reflect the goals of the community of inquiry approach, encouraging critical, creative, caring, and collaborative efforts in the classroom. See https://www. sapere.org.uk/.

\section{References}

Ackman, Emily, Thomas G. White, and James S. Kim. 2016. "Facilitating Policymakers' Use of the Evidence on Summer Loss and Summer Programs." In The Summer Slide: What We Know and Can Do about Summer Learning Loss, edited by Karl Alexander, Sarah Pitcock, and Matthew Boulay, 284-298. New York: Teachers College Press. 
Alexander, Karl, and Barbara F. Condliffe. 2016. "Summer Setback in Baltimore: A Review and Update." In The Summer Slide: What We Know and Can Do about Summer Learning Loss, edited by Karl Alexander, Sarah Pitcock, and Matthew Boulay, 23-34. New York: Teachers College Press.

Alexander, Karl, Sarah Pitcock, and Matthew Boulay, eds. 2016. The Summer Slide: What We Know and Can Do about Summer Learning Loss. New York: Teachers College Press.

Alexander, Karl L., Doris. R. Entwisle, and Linda S. Olson. 2007. "Lasting Consequences of the Summer Learning Gap." AmericanSociological Review 72: 167-180. https://doi.org/10.1177/000312240707200202

Alexander, Karl L., Doris R. Entwisle, and Linda S. Olson. 2014. The Long Shadow: Family Background, Disadvantaged Urban Youth and the Transition to Adulthood. New York: The Russell Sage Foundation.

Allington, Richard L., and Anne McGill-Franzen. 2018. Summer Reading: Closing the Rich/Poor Reading Achievement Gap. New York: Teachers College Press, Columbia University.

Arain, Mariam, Maliha Haque, Lina Johal, Puja Mathur, Wynand Nel, Afsha Rais, Ranbir Sandhu, and Sushil Sharma. 2013. "Maturation of the Adolescent Brain." Neuropsychiatric Disease and Treatment 9: 449-461. https://doi.org/10.2147/NDT.S39776

Atteberry, Allison, and Andrew McEachin. 2016. "School's Out: Summer Learning Loss Across Grade Levels and School Contexts in the United States Today.” In The Summer Slide: What We Know and Can Do about Summer Learning Loss, edited by Karl Alexander, Sarah Pitcock, and Matthew Boulay, 35-54. New York: Teachers College, Columbia University.

Augustine, Catherine H., Jennifer Sloan McCombs, John F. Pane, Heather L. Schwartz, Jonathan Schweig, Andrew McEachin, and Kyle Siler-Evans. 2016. Learning from Summer: Effects of Voluntary Summer Learning Programs on Low-Income Urban Youth. Santa Monica, CA: RAND Corporation. https://doi.org/10.7249/RR1557

Berliner, David C. 2009. "Poverty and Potential: Out-of-School Factors and School Success." Boulder and Tempe: Education and the Public Interest Center \& Education Policy Research Unit.

Bohnert, Amy, Nicole Zarrett, and Amy Heard. 2016. "The Roles of Summertime in Child Obesity: Risks and Opportunities. In The Summer Slide: What We Know and Can Do about Summer Learning Loss, edited by Karl Alexander, Sarah Pitcock, and Matthew Boulay, 161-176. New York: Teachers College, Columbia University.

Bohnert, Amy, Dorothy McLeod, Heather Marshall, and Kathryn Grant. 2016. "Summertime and Youth's Psychosocial Well-Being." In The Summer Slide: What We Know and Can Do about Summer Learning Loss, edited by Karl Alexander, Sarah Pitcock, and Matthew Boulay, 177-189. New York: Teachers College, Columbia University. 
Borman, Geoffrey D., and Matthew Boulay. 2004. Summer Learning: Research, Policies and Programs. Mahwah, NJ: Lawrence Erlbaum Associates. https://doi.org/10.4324/9781410610362

Borman, Geoffrey D., Alex Schmidt, and Michelle Hosp. 2016. "A National Review of Summer School Policies and the Evidence Supporting Them." In The Summer Slide: What We Know and Can Do about Summer Learning Loss, edited by Karl Alexander, Sarah Pitcock, and Matthew Boulay, 90-107. New York: Teachers College, Columbia University.

Cataldi, Emily Forrest, Christopher T. Bennett, Xianglei Chen, and Sean Simone. 2018. "First-Generation Students: College Access, Persistence, and Postbachelor's Outcomes." National Center for Education Statistics, U.S. Department of Education.

Clance, Pauline R., and Suzanne A. Imes. 1978. “The Imposter Phenomenon in High Achieving Women: Dynamics and Therapeutic Intervention." Psychotherapy: Theory, Research \& Practice 15, no. 3: 241-247. https://doi.org/10.1037/h0086006

Cokley, Kevin, Leann Smith, Donte Bernard, Ashley Hurst, Stacey Jackson, Steven Stone, Olufunke Awosogba, Chastity Saucer, Bailey Marlon, and Davia Roberts. 2017. "Impostor Feelings as a Moderator and Mediator of the Relationship Between Perceived Discrimination and Mental Health Among Racial/Ethnic Minority College Students." Journal of Counseling Psychology 64, no. 2: 141-154. https://doi.org/10.1037/cou0000198

Coleman, James S. 1988. "Social Capital in the Creation of Human Capital." American Journal of Sociology 94: S95-120. https://doi.org/10.1086/228943

Cooper, Harris, Barbara Nye, Kelly Charlton, James Lindsay, and Scott Greathouse. 1996. "The Effects of Summer Vacation on Achievement Test Scores: A Narrative and Meta-analytic Review." Review of Educational Research 66, no. 3: 227-268. https://doi.org/10.3102/00346543066003227

Deutsch, Nancy L. 2017. After-School Programs to Promote Positive Youth Development. Advances in Child and Family Policy and Practice. Cham, Switzerland: Springer.

Dobbie, Will, and Roland G. Fryer. 2011. "Are High-Quality Schools Enough to Increase Achievement among the Poor? Evidence from the Harlem Children's Zone." American Economic Journal: Applied Economics 3: 158-187. https://doi.org/10.1257/app.3.3.158

Downey, Douglas B. 2016. "Schools, Families and Inequality: Strong Empirical Patterns in Search of Strong Theory." In The Summer Slide: What We Know and Can Do about Summer Learning Loss, edited by Karl Alexander, Sarah Pitcock, and Matthew Boulay, 11-22. New York: Teachers College, Columbia University.

Downey, Douglas B., Paul T. von Hippel, and Beckett A. Broh. 2004. "Are Schools the Great Equalizer? Cognitive Inequality During the Summer Months and the School Year." American Sociological Review 69: 613-635.

https://doi.org/10.1177/000312240406900501 
Entwisle, Doris R., Karl L. Alexander, and Linda S. Olson. 1997. Children, Schools, and Inequality. Boulder: Westview Press.

Erikson, Erik. 1963. Youth: Change and Challenge. New York: Basic Books.

Erikson, Erik. 1968. Identity: Youth and Crisis. New York: Norton.

Frederick, Shane. 2005. "Cognitive Reflection and Decision Making." The Journal of Economic Perspectives 19, no. 4: 25-42. https://doi.org/10.1257/089533005775196732

Fredricks, Jennifer A., Phyllis C. Blumenfeld, and Alison H. Paris. 2004. "School Engagement: Potential of the Concept, State of the Evidence." Review of Educational Research 74, no. 1: 59-109. https://doi.org/10.3102/00346543074001059

Friedlaender, Diane, Dion Burns, Heather Lewis-Charp, Channa M. Cook-Harvey, and Linda Darling-Hammond. 2014. "Student-Centered Schools: Closing the Opportunity Gap." Stanford, CA: Stanford Center for Opportunity Policy in Education.

Garrison, D. Randy. 2011. E-Learning in the 21st Century: A Framework for Research and Practice. New York: Routledge. https://doi.org/10.4324/9780203838761

Gold, Bonnie, and Roger Simons. 2008. Proof and Other Dilemmas: Mathematics and Philosophy. Ann Arbor, MI: Mathematical Association of America. https://doi.org/10.5948/UPO9781614445050

Hall, Georgia, Kristen Fay Poston, and Julie Dennehy. 2017. "Summer Learning Programs: Investigating Strengths and Challenges." In After-School Programs to Promote Positive Youth Development, edited by Nancy J. Deutsch, 1-20. Cham, Switzerland: Springer. https://doi.org/10.1007/978-3-319-59141-4_1

Heyns, Barbara. 1978. Summer Learning and the Effects of Schooling. New York: Academic Press.

Heyns, Barbara. 1987. "Schooling and Cognitive Development: Is There a Season for Learning?" Child Development 58, no. 5: 1151-1160.

https://doi.org/10.2307/1130611

Hutchison, Michol. 2017. “Influence of First Generation Status on Students' Perceptions of Faculty." College Quarterly 20, no. 1: 1

Kaplan, Sandra. 1994. Differentiating the Core Curriculum and Instruction to Provide Advanced Learning Opportunities. Sacramento: California Department of Education and California Association for the Gifted.

Kenyon, Erik, Diane Terorde-Doyle, and Sharon Carnahan. 2019. Ethics for the Very Young: A Philosophy Curriculum for Early Childhood Education. Lanham, MD: Rowman and Littlefield.

Kim, James S., and David M. Quinn. 2013. "The Effects of Summer Reading on Low-income Children's Literacy Achievement from Kindergarten to Grade 8: A Meta-analysis of Classroom and Home Interventions." Review of Educational Research 83, no. 3: 386-431. https://doi.org/10.3102/0034654313483906 
Kizel, Arie. 2016. "Philosophy with Children as an Educational Platform for SelfDetermined Learning." Cogent Education 3: Article 1244026. https://doi.org/10.1080/2331186X.2016.1244026

Koury, Abel, Laura Justice, Hui Jiang, and Jessica Logan. 2019. "Summer Learning: Who Gains, Who Slides, and Does It Matter?" Sage Submissions. Preprint. https://doi.org/10.31124/advance.8636720.v1

Lee, Valerie, and David T. Burkham. 2002. Inequality at the Starting Gate: Social Background Difference in Achievement as Children Begin School. Washington, DC: Economic Policy Institute.

Levin, Henry M., and Clive R. Belfield. 2002. "Families as Contractual Partners in Education." UCLA Law Review 49: 1799-1824.

Lipman, Matthew. 1988. Philosophy Goes to School. Philadelphia, PA: Temple University Press.

Lipman, Matthew, and Ann Margaret Sharp. 1979. "Some Educational Presuppositions of P4C." Thinking: The Journal of Philosophy for Children 1, no. 2: 47-50. https://doi.org/10.5840/thinking19791241

Lipman, Matthew, and Ann Margaret Sharp. 1988. "Philosophy for Children." Thinking: The Journal of Philosophy for Children 7, no. 4: 32-35.

https://doi.org/10.5840/thinking1988748

Marcia, James. 1980. "Identity in Adolescence." Handbook of Adolescent Psychology 5: $145-160$.

Martin, Andrew J. 2001. "The Student Motivation Scale: A Tool for Measuring and Enhancing Motivation." Journal of Psychologists and Counsellors in Schools 11: 1-20. https://doi.org/10.1017/S1037291100004301

Matthews, Gareth B. 1980. Philosophy and the Young Child. Cambridge, MA: Harvard University Press.

Matthews, Gareth B. 1984. Dialogues with Children. Cambridge, MA: Harvard University Press.

McCombs, Jennifer S., Catherine Augustine, Heather Schwartz, Susan Bodilly, Brian McInnis, Dahlia Lichter, and Amanda Brown Cross. 2012. "Making Summer Count: How Summer Programs Can Boost Children's Learning." Education Digest: Essential Readings Condensed for Quick Review 77, no. 6: 47-52. https://doi.org/10.1037/e525802012-001

McCombs, Jennifer S., John F. Pane, Catherine H. Augustine, Heather L. Schwartz, Paco Martorell, and Laura L. Zakaras. 2015. First Outcomes from the National Summer Learning Study (Brief No. RB-9819-WF). Santa Monica, CA: RAND Corporation. https://doi.org/10.7249/RB9819

McEachin, Andrew, Catherine Augustine, and Jennifer McCombs. 2016. "Best Practices in Summer Programming." In The Summer Slide: What We Know and Can Do about Summer Learning Loss, edited by Karl Alexander, Sarah Pitcock, and Matthew Boulay, 193-207. New York: Teachers College, Columbia University. 
McLaughlin, Brenda, and Sarah Pitcock. 2009. "Building Quality in Summer Learning Programs: Approaches and Recommendations." White Paper commissioned by The Wallace Foundation.

Miller, Beth M. 2007. “The Learning Season: The Untapped Power for Summer to Advance Student Achievement." Paper commissioned by the Nellie Mae Education Foundation. Quincy, MA: Nellie Mae Foundation.

Millet, Stephan, and Alan Tapper. 2012. "Benefits of Collaborative Philosophical Inquiry in Schools." Educational Philosophy \& Theory 44, no. 5: 546-567. https://doi.org/10.1111/j.1469-5812.2010.00727.x

Mohr Lone, Jana. 2012. "Teaching Pre-College Philosophy: The Cultivation of Philosophical Sensitivity." In Philosophy and Education: Introducing Philosophy to Young People, edited by Jana Mohr Lone and Roberta Israeloff, 13-22. Newcastle upon Tyne: Cambridge Scholars Press.

Mohr Lone, Jana. 2013. "Philosophical Sensitivity." Metaphilosophy 44, nos. 1-2: 171-186.

Mohr Lone, Jana, and Michael Burroughs. 2016. Philosophy in Education: Questioning \& Dialogue in Schools. Lanham, MD: Rowman \& Littlefield. https://doi.org/10.1111/meta.12018

Mohr Lone, Jana, and Roberta Israeloff, eds. 2012. Philosophy and Education: IntroducingPhilosophy to Young People. Newcastle upon Tyne: Cambridge Scholars Press.

National Center for Education Statistics (NCES). 2012. Improving the Measurement of Socioeconomic Status for the National Assessment of Educational Progress: A Theoretical Foundation. Recommendations to the National Center for Education Statistics. https://nces.ed.gov/nationsreportcard/researchcenter/ socioeconomic_factors.aspx.

Phillips, Kristopher G. 2018. “The Kids are Alright: Philosophical Dialogue and the Utah Lyceum." Precollege Philosophy and Public Practice 1: 42-57. https://doi.org/10.5840/p4201810241

Pitcock, Sarah. 2016. "Summer Learning and the Opportunity Gap." In The Summer Slide: What We Know and Can Do about Summer Learning Loss, edited by Karl Alexander, Sarah Pitcock and Matthew Boulay, 70-89. New York: Teachers College Press.

Pitcock, Sarah. 2018. "The Case for Summer Learning: Why Supporting Students and Families All Year IsVitally Important.” American Educator 42, no. 1: 4-8.

Portz, John. 2004. "Summer School 2000 and 2001: The Boston Public Schools Transition Services Program.” In Summer Learning: Research, Policies and Programs, edited by Geoffrey D. Borman and Matthew Boulay, 103-119. Mahwah, NJ: Lawrence Erlbaum Associates. 
Repko, Allen F. 2009. "Transforming an Experimental Innovation into a Sustainable Academic Program at the University of Texas-Arlington." In The Politics of Interdisciplinary Studies: Essays on Transformations in American Undergraduate Programs, edited by Tanya Augsburg and Stuart Henry. Jefferson, NC: McFarland.

Repko, Allen F., William H. Newell, and Rick Szostak. 2011. Case Studies in Interdisciplinary Research. Los Angeles, CA: Sage Publications. https://doi.org/10.4135/9781483349541

Roderick, Melissa, Brian A. Jacob, and Anthony S. Bryk. 2004. "Summer in the City: Achievement Gains in Chicago's Summer Bridge Program." In Summer Learning: Research, Policies and Programs, edited by Geoffrey D. Borman and Matthew Boulay, 73-102. Mahwah, NJ: Lawrence Erlbaum Associates.

Sharp, Ann Margaret. 1987. "What is a 'Community of Inquiry'?" Journal of Moral Education 16, no. 1: 37-45. https://doi.org/10.1080/0305724870160104

Spaeth, J. L. 1976. "Cognitive Complexity: A Dimension Underlying the Socioeconomic Achievement Process." In Schooling and Achievement in American Society, edited by W. H. Sewall, R. M. Hauser, and D. L. Featherman, 103-131. New York: Academic Press.

Swanson, Elise, Katherine Kopotic, Gema Zamarro, Jonathan Mills, Jay Greene, and Gary Ritter. 2019. "An Evaluation of the Educational Impact of College Campus Visits: A Randomized Experiment.” EDRE Working Paper No. 2019-002. https://doi.org/10.2139/ssrn.3329946

Terzian, Mary, Kristin Anderson Moore, and Kathleen Hamilton. 2009. "Effective and Promising Summer Learning Programs and Approaches for Economically-Disadvantaged Children and Youth." White Paper commissioned by The Wallace Foundation. Washington, DC: Child Trends. https://doi.org/10.1037/e616472009-001

Trickey, S., and K. J. Topping. 2004. "Philosophy for Children: A Systematic Review. Research Papers in Education." Research Papers in Education 19, no. 3: 365-380. https://doi.org/10.1080/0267152042000248016

Trickey, S., and K. J. Topping. 2007. "Collaborative Philosophical Enquiry for School Children: Cognitive Gains at 2-year Follow Up." British Journal of Educational Psychology 77, no. 4: 787-796. https://doi.org/10.1348/000709907X193032

Tuttle, Christina Clark, Brian Gill, Philip Gleason, Virginia Knechtel, Ira NicholsBarrer, and Alexandra Resch. 2013. "KIPP Middle Schools: Impacts on Achievement and Other Outcomes. Final Report." Mathematica Policy Research, Inc.

von Hippel, Paul, and Caitlin Hamrock. 2019. "Do Test Score Gaps Grow Before, During, or Between the School Years? Measurement Artifacts and What We Can Know in Spite of Them." Sociological Science 6: 43-80.

https://doi.org/10.15195/v6.a3 
Walpole, MaryBeth. 2003. "Socioeconomic Status and College: How SES Affects College Experiences and Outcomes." Review of Higher Education 27: 45-73. https://doi.org/10.1353/rhe.2003.0044

Wartenberg, Thomas. 2009. Big Ideas for Little Kids: Teachign Philosophy Through Children's Literature. Lanham: Rowman \& Littlefield.

Wartenberg, Thomas E., ed. 2019. Philosophy in Classrooms and Beyond: New Approaches to Picture-Book Philosophy. Lanham: Rowman \& Littlefield Publishers. 